\title{
Aspect of Design Functionality on Communal Mosque in Muslim and Non-Muslim Country
}

\author{
Nurul 'Athiqah Baharudin, Alice Sabrina Ismail \\ Centre of Architecture, Faculty of Built Environment, \\ Universiti Teknologi Malaysia \\ nathiqah4@live.utm.my
}

\begin{abstract}
The objective of this paper is to provide the description of modern communal mosque in Muslim and non-Muslim countries. Comparative study will help to understand the modern mosques development and fulfil the desire of the Muslim community to produce a sustainable environment. Qualitative research, text interpretation, and observation are used to introduce new recommendations for future communal mosque design.

Keywords: Sustainable; mosque; semiotic; community

eISSN: 2398-4279 @ 2016. The Authors. Published for AMER ABRA by e-International Publishing House, Ltd., UK.. This is an open access article under the CC BY-NC-ND license (http://creativecommons.org/licenses/by-ncnd/4.0/). Peer-review under responsibility of AMER (Association of Malaysian Environment-Behaviour Researchers), ABRA (Association of Behavioural Researchers on Asians) and cE-Bs (Centre for EnvironmentBehaviour Studies), Faculty of Architecture, Planning \& Surveying, Universiti Teknologi MARA, Malaysia.

https://doi.org/10.21834/ajqol.v1i2.24
\end{abstract}




\subsection{Introduction}

There are a vast number of studies on modern mosque were carried out by previous research. This study is vital because the function and role of the mosque are widely misinterpreted in the present Muslim country (M. Tajuddin R. 1998). Mosque should be able to develop a sustainability for surrounding community but the modern mosque designs seem unsuccessful (M. Zafrullah M.T, 2009). Influence of social changes and politic results the mosques becoming national symbol that is purposely built in mega scale in urban fabrics. The mosque emphasizes more on aesthetic rather than function either in form or spatial arrangement (Spahic 0, 2010). The function of mosque varies depending on setting of mosque and policy of the country. Modern mosque in a non-Muslim country built to represent Muslim existence while mosques in a Muslim country represent as an Islamic nation, so this is the reason of the needs of sustainable design in a mosque. The use of materials, energy usage, settings and development of space within environmentally approach in the design of the mosque is vital and give advantage to Muslim society. Quality in architectural design is to fulfill the need of the society (Abu Samah Z., 2003). Idea of sustainability, not only minimize the negative environmental impact but will enhance efficiency usage of space in a religious building

\subsection{Background Study}

Community is a small social group consisting of individuals with same characteristics and values. It has demands and appeal which can be fulfilled to ensure a balanced public living environment by providing versatile community spaces (Peck, 1998; Wates, Nick, 1987). These spaces are considered as community architecture. Mankind was created to contribute to and

develop a better world (Hafazah Abd K., 2012). Various observations on human interactions have been emphasized by most religions (M. Noor M. et.al, 2012). Main focus of this paper will be on the mosque as religious building of Islam.

The mosque, or 'Sajada, which means the place for sujud, have been characterized into four groups. Communal mosque or jami' mosque as one of the groups is the closest idea to real community mosque. The idea of community mosque comes from the prophet mosque that been as par-excellence mosque example that should be follow by Muslim when built the mosque (Rosniza O., 2007). Not only serving as a holy-place for worship, also meant for communal purposes (Spahic O., 2010).Keles R.(2012) mention that a mosque should reflect the religious, spiritual and belief system of Muslim society, not towards chasing the lavishness and national identity. The community surrounding will be improved if the design of the mosque follows the needs of mankind and religious (Maran R.W., 2012). Previous scholars already outline the guideline of designing community mosque in a sustainable way possible. This paper will determine and discuss the finding on sustainable element approach in both mosque design including the form and space. 


\subsection{Criteria of communal mosque on sustainable approach design}

These characteristics of sustainable form design in communal mosques are widely defined by previous scholars in 5 main criteria's of form and spatial organization.

Table 1: Five elements to look at sustainable modern mosque design

\begin{tabular}{|c|c|c|}
\hline & ELEMENT & CHARACTER \\
\hline \multirow[t]{4}{*}{ FORM } & Facade & $\begin{array}{l}\text { Sustainability in the design of mosque can be seen on the } \\
\text { organizational element especially roofing, door, window and } \\
\text { floor (Holod R \&Khan,1997). }\end{array}$ \\
\hline & $\begin{array}{l}\text { Ornamentation, } \\
\text { detailing, structure } \\
\text { elements and material } \\
\text { usage }\end{array}$ & $\begin{array}{l}\text { The choose of material on portraying naturalistic image and } \\
\text { represent local identity which repond to the existing context } \\
\text { (M.Tajuddin R.,1998; Rosniza O.,2007; Hamid, 2012). It also } \\
\text { introduced sense of sustainability if the elements support the } \\
\text { function not merely as aesthetic purposes. }\end{array}$ \\
\hline & Setting & $\begin{array}{l}\text { Idea of no wastage reflects on choice of setting to build the } \\
\text { mosque. The criteria of sustainability of building placement } \\
\text { are location within walking distance, multiple accesses from } \\
\text { community point (Hamid, 2012). }\end{array}$ \\
\hline & Scale & $\begin{array}{l}\text { Building scale within context will provide a friendly } \\
\text { environment to the user. Monumental building needs more } \\
\text { energy and building materials (Hamid, 2012). The proportional } \\
\text { building is always good that give high comfort level to the } \\
\text { user(Nadzirah et.al,2011) }\end{array}$ \\
\hline SPACE & Spatial organisation & $\begin{array}{l}\text { It can be divide into } 3 \text { type which is hierarchy, zoning and } \\
\text { circulation. Hierarchy is talking about the arrangement of } \\
\text { interior by storey or land setting. Placement that not over } \\
\text { power the flora context will help to give cooling effect to the } \\
\text { area. As for zoning, the arrangement for type of space and } \\
\text { multipurpose space to maximize the usage. The courtyard } \\
\text { and open air space help to breeze the indoor area. Circulation } \\
\text { help to give an organic design form. The good circulation will } \\
\text { reduce human energy use and tendency to encourage more } \\
\text { social interaction in space. }\end{array}$ \\
\hline
\end{tabular}

\subsection{Methodology}

This study involves multiple methods by referring to semiotics that gives advantage to reveal the ideology of designer denotes to hermeneutic applied on the design of built form and space. The methodology will gain deeper understanding for the study.

\subsection{Semiotic as research methodology}

Semiotic is use to study sign and symbol (Fiske, 1990). This theory helps to describe how human mirror their thought and applies it to understand the meaning of 'sign'. According to Hawkes (2003) 'sign' may be an act, symbol or gesture used to convey an idea, a desire, information, or a command. Saussure model of semiotic using dyadic which is the signifier as sound and signified as a mental concept (thought). This theory is vital as can help to understand the process of giving meaning on this two modern communal mosque as a meaningful sign. 


\section{Sistem dyadic \\ Signified $\longleftrightarrow$ Signifier}

Figure 1: System theory of Saussure: dyadic

Saussure theory has limitation that cannot deal with social, cultural, expression and conventions. Works by Gottdiener extend and elaborates Saussure's work have been used because he adds on the cultural context (ideology) behind the sign of a built environment. $\mathrm{He}$ is known as socio-semiotics that stand the process of giving the built form meaning must include socio-culture in between signifier and signified. Gottdiener (1995) suggested that to understand the meaning of the built environment; one should define 'sign' as a symbol (building form). Researcher should study how the built form as a 'sign' is shaped by social interests and ideologies, and adapted as society changes. In this case, to understand built form as a sign, one should define it from social ideology and an architectural ideology point of view. This architectural ideology aspect much relates to the architectural object itself and to the morphological elements that make the built form. Therefore, Ferdinand Saussure and Mark Gottdiener theory is adapted because the theories will help to describe and define the meaning of communal mosque built form as a meaningful 'sign'. Data collection for this study will use direct observation method and use indicator as a guide. Each of these indicators will be analyzed as described in the table below by referring to the underpinning theories as proposed by prominent architectural scholars.

Table 2: Theory chosen to analyze the design of the mosque

\begin{tabular}{|l|l|l|l|}
\hline \multicolumn{1}{|c|}{$\begin{array}{c}\text { Data collection } \\
\text { method }\end{array}$} & Building variables & Theory to analyse & \multicolumn{1}{|c|}{ Process } \\
\hline $\begin{array}{l}\text { Observation } \\
\text {-understanding on field } \\
\text { work(Mulhall A.,2002) } \\
\text {-use 5 variables } \\
\text { establish from the } \\
\text { literature review }\end{array}$ & Façade & $\begin{array}{l}\text { Shatha(2004) layering } \\
\text { theory analyse }\end{array}$ & $\begin{array}{l}\text {-Use system of layering } \\
\text {-Clarify overall } \\
\text { structure layer by layer } \\
\text { until the additional } \\
\text { element } \\
\text {-Identifying each } \\
\text { element and } \\
\text { arrangement of façade } \\
\text { element }\end{array}$ \\
\hline & $\begin{array}{l}\text { Detailing, structure and } \\
\text { ornamentation }\end{array}$ & $\begin{array}{l}\text { Wright(1939) Organic } \\
\text { theory }\end{array}$ & $\begin{array}{l}\text {-Identify and observe } \\
\text { elements } \\
\text {-Observe the type of } \\
\text { material use. }\end{array}$ \\
\hline & Setting & $\begin{array}{l}\text { Wright(1939) Organic } \\
\text { theory }\end{array}$ & $\begin{array}{l}\text {-Observe the area } \\
\text {-Clarify basic structure }\end{array}$ \\
\hline & Scale & $\begin{array}{l}\text { Ching(1994) Proportion } \\
\text { theory } \\
\text {-scale within building } \\
\text { and context } \\
\text {-scale within building } \\
\text { and human scale }\end{array}$ & $\begin{array}{l}\text {-Observe the size } \\
\text { within mosque and } \\
\text { surrounding } \\
\text {-Observe sectional of } \\
\text { mosque using drawing }\end{array}$ \\
\hline & Spatial organization & $\begin{array}{l}\text { Hillier and } \\
\text { Hanson,1996; dovey } \\
\text { spatial syntax theory }\end{array}$ & $\begin{array}{l}\text {-Analyse floor plan by } \\
\text { jot down the main } \\
\text { entrance and the } \\
\text { movement and } \\
\text { placement of space }\end{array}$ \\
\hline
\end{tabular}




\subsection{Hermeneutic as research methodology}

Hermeneutic is usually known as the theory to interpret text either document, verbal, communication, interview and so on. For this study, hermeneutics circle that refers primarily to the theory of knowledge initiated by Hadager is adapted to understand the meaning of the text. In this sense, interpretation of knowledge from written text must be in a cyclic manner which involves a series of phases. The phases will involve coding method that helps to analyze the text in a systematic manner. Firstly, the text will be read as open code that the researcher need to go through the reading first then jot down the code, subcoding and theme. After that, the finding will be compared to each other to know the intention of ideology behind the design of the mosque. This theory will help to make deeper understanding on the mental concept of the mosque design that portray their true meaning.

Two selected case study have been chosen that found in Muslim country and nonMuslim country. Both mosques show various active activity happening in their mosque that defined from the preliminary studies and literature review. The different setting of mosque helps to justify the design element of a mosque in different beliefs and culture but portray the functional value compare to any other mosque.

\subsection{Results and Discussions}

\subsection{Case study}

In 1990's, Seri Petaling mosque that belong to the most prominent non organizational da'wah movement in Malaysia, tabligh has been built. The da'wah group came to Malaysia in the early of 50's then embark the phenomena of da'wah in Malaysia in 1970's. Originally, this da'wah group is known as Indian Muslim movement because of where the tabligh origin but after 1970's, Malay community start to join the movement (Abd. Rahman Abd., 2007). This mosque known as jami' mosque. It is under the control of Islamic religious department (JAKIM). Another mosque is An-Nahdhah Mosque as one of the $3^{\text {rd }}$ phase mosque development in Singapore that specifically built within the concept of community mosque. It is located in Bishan, Singapore. This new generation of mosque serving both religious and spiritual needs of the Muslim community. It is located in a modern city, Singapore and surrounding by multi-ethnic under the non-Muslim ruler. So, both will be different in terms of policy and surrounding context.

Table 3: Figure of characteristic element on modern mosque design

\begin{tabular}{|l|l|l|}
\hline & Masjid Seri Petaling & Masjid An-Nahdhah \\
\hline
\end{tabular}




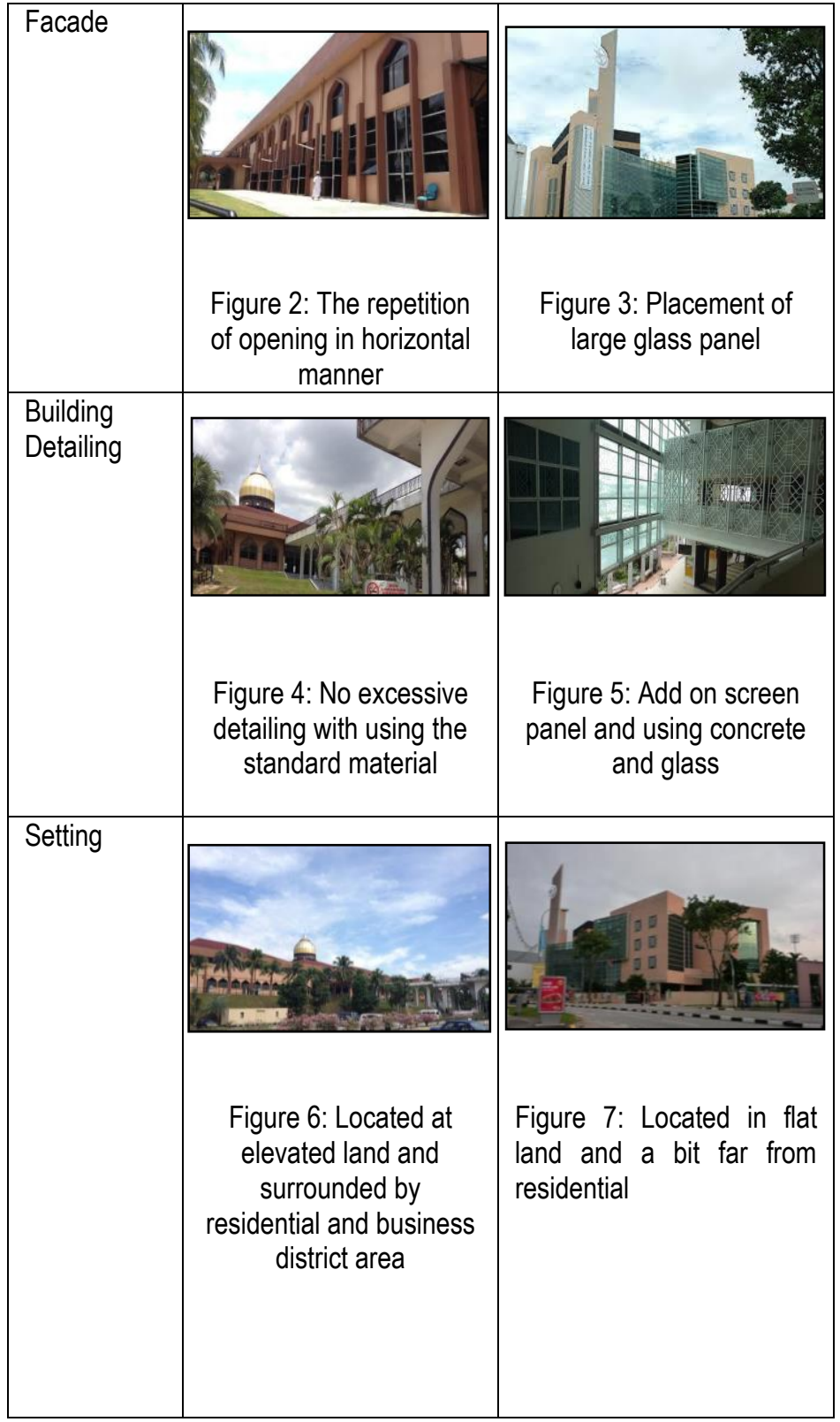




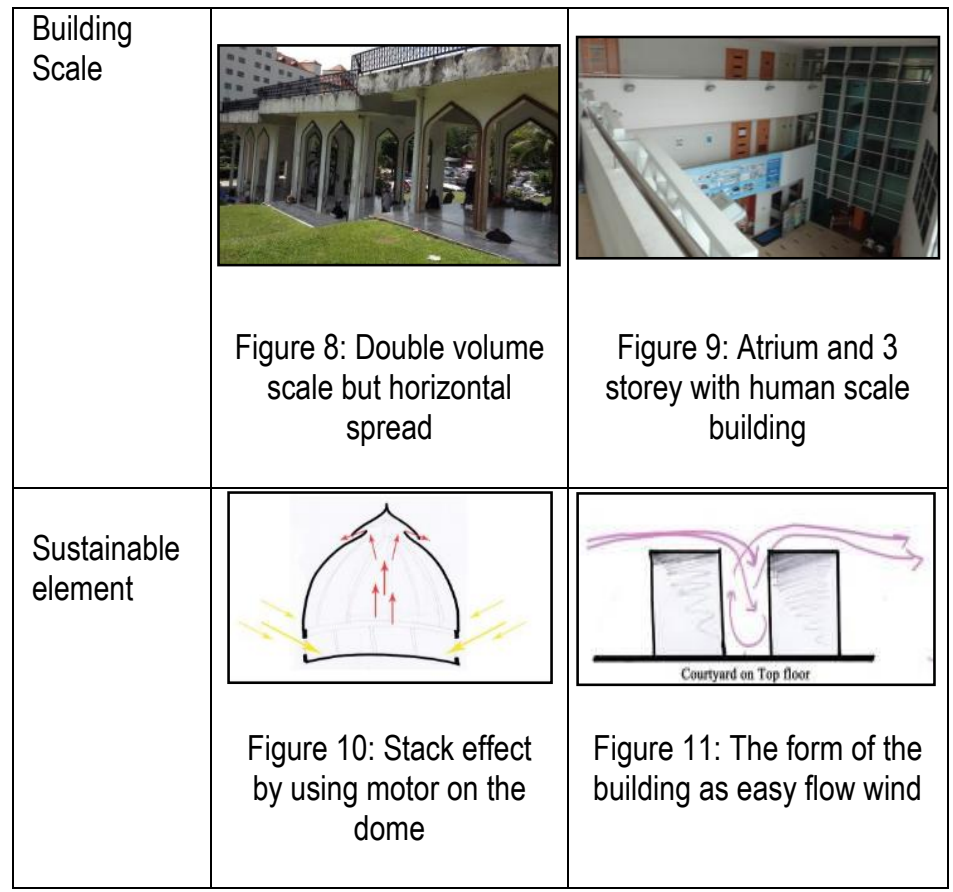

Preliminary observation has been done, and it shows that both mosques reflect the element that not only sensitive to communal needs, but also using the sustainable approach within their limitation. The similarity and differences of the element list below are to have deeper understanding on how the element of the mosque portrays the sustainable design approach.

Table 4: The understanding on the elements of the mosque potrays the sustainable design approach

\begin{tabular}{|c|c|c|c|c|c|}
\hline & & $\begin{array}{l}\text { Sust } \\
\text { apprc }\end{array}$ & $\begin{array}{l}\text { nable } \\
\text { ach }\end{array}$ & $\begin{array}{l}\text { Element of su } \\
\text { approach }\end{array}$ & tainable design \\
\hline $\begin{array}{l}\text { Building } \\
\text { indicators }\end{array}$ & & $\begin{array}{l}\text { Simil } \\
\text { ar }\end{array}$ & Diff. & $\begin{array}{l}\text { Seri Petaling } \\
\text { mosque }\end{array}$ & $\begin{array}{l}\text { An-Nahdhah } \\
\text { mosque }\end{array}$ \\
\hline Form & 을 & & & & \\
\hline
\end{tabular}




\begin{tabular}{|c|c|c|c|c|c|}
\hline \multirow[t]{2}{*}{ Facade } & 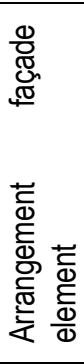 & & $X$ & $\begin{array}{l}\text { Window and } \\
\text { door arrange in } \\
\text { horizontal and } \\
\text { in tiers. } \\
\text {-allow natural } \\
\text { light penetrate } \\
\text { and allowing } \\
\text { natural } \\
\text { ventilation. }\end{array}$ & $\begin{array}{l}\text { Giant glass } \\
\text { panel on south } \\
\text { façade } \\
\text {-Trap more } \\
\text { heat within } \\
\text { open concept } \\
\text {-Free flow } \\
\text { ventilation }\end{array}$ \\
\hline & 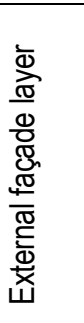 & & $X$ & $\begin{array}{l}\text { Coping } \\
\text { surround the } \\
\text { opening } \\
\text {-control the } \\
\text { rainwater flow } \\
\text { into the interior } \\
\text { and as sun } \\
\text { shade. }\end{array}$ & - \\
\hline \multirow[t]{2}{*}{ Detailing } & 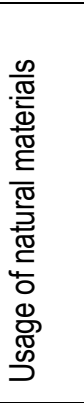 & $X$ & $X$ & $\begin{array}{l}\text { Timber panel at } \\
\text { the main prayer } \\
\text { ceiling } \\
\text {-Cooling effect } \\
\text { and reduce } \\
\text { heat absorption } \\
\text { Marble floor } \\
\text {-Cooling effect } \\
\text { \& light } \\
\text { reflection }\end{array}$ & $\begin{array}{l}\text { Ceramic floor } \\
\text {-Cooling effect } \\
\text { \& light reflection }\end{array}$ \\
\hline & 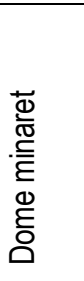 & & $X$ & $\begin{array}{lr}\text { Stack effect } \\
\text { system } & \text { on } \\
\text { dome } & \text { with } \\
\text { motor } & \\
\text { generator } & \\
\text {-Penetrate } & \\
\text { light } & \end{array}$ & - \\
\hline
\end{tabular}




\begin{tabular}{|c|c|c|c|c|c|}
\hline & 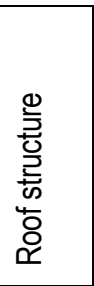 & & $X$ & $\begin{array}{l}\text { Tapered roof } \\
\text { for rainwater } \\
\text { flow } \\
\text { Natural light } \\
\text { penetrate at } \\
\text { transparent } \\
\text { roof. }\end{array}$ & $\begin{array}{l}\text { Flat roof and } \\
\text { use as } \\
\text { madrasah open } \\
\text { courtyard-the } \\
\text { use gutter } \\
\text { system. }\end{array}$ \\
\hline \multirow[t]{4}{*}{ Setting } & 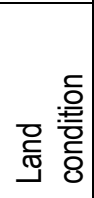 & $X$ & & $\begin{array}{l}\text { Reduce } \\
\text { wastage by } \\
\text { done on Hill } \\
\text { land setting }\end{array}$ & $\begin{array}{l}\text { Natural flat land } \\
\text { Isolated }\end{array}$ \\
\hline & $\begin{array}{l}\frac{0}{0} \\
\frac{0}{\pi} \\
\frac{\pi}{0} \\
.0\end{array}$ & & $X$ & $\begin{array}{l}\text { Near to } \\
\text { residential and } \\
\text { business area- } \\
\text { less use of } \\
\text { car/motor } \\
\text { neutral } \\
\text { environment. }\end{array}$ & - \\
\hline & 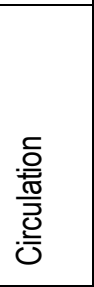 & & $X$ & $\begin{array}{l}\text { Multiple access } \\
\text { and minimum } 1 \\
\text { access only for } \\
\text { vehicle- } \\
\text { encourage } \\
\text { walking } \\
\text { environment }\end{array}$ & $\begin{array}{l}\text { Location setting } \\
\text { in easy access } \\
\text { and near to } \\
\text { main road. }\end{array}$ \\
\hline & 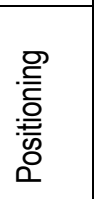 & $X$ & & $\begin{array}{l}\text { Maximum } \\
\text { surface area on } \\
\text { east and west }\end{array}$ & $\begin{array}{l}\text { Minimum } \\
\text { surface area on } \\
\text { east and west }\end{array}$ \\
\hline $\begin{array}{l}\text { Building } \\
\text { scale }\end{array}$ & 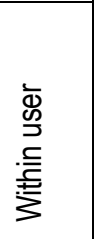 & $X$ & & $\begin{array}{l}\text { Proportionate } \\
\text { with amount of } \\
\text { user } \\
\text {-Comfort and } \\
\text { close to } \\
\text { environment }\end{array}$ & \\
\hline
\end{tabular}




\begin{tabular}{|c|c|c|c|c|}
\hline & 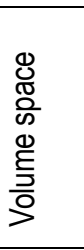 & $X$ & $\begin{array}{l}\text { Double volume } \\
\text { for the whole } \\
\text { building } \\
\text {-Speed the } \\
\text { changes flow of } \\
\text { hot and cold air }\end{array}$ & $\begin{array}{l}\text { Triple volume } \\
\text { atrium- } \\
\text { maximise heat } \\
\text { release } \\
\text { outside. }\end{array}$ \\
\hline & 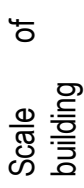 & $X$ & $\begin{array}{l}\text { Large opening } \\
\text {-max natural } \\
\text { ventilation and } \\
\text { natural light }\end{array}$ & $\begin{array}{l}\text { Large opening- } \\
\text { penetrate } \\
\text { natural lighting }\end{array}$ \\
\hline & 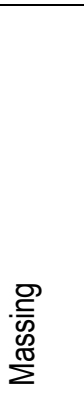 & $X$ & $\begin{array}{l}\text { Play of solid } \\
\text { and void for } \\
\text { easy access } \\
\text { flow of natural } \\
\text { ventilation }\end{array}$ & $\begin{array}{l}\text { Solid and void } \\
\text { punctured up to } \\
\text { triple volume } \\
\text { for easy access } \\
\text { natural } \\
\text { ventilation }\end{array}$ \\
\hline $\begin{array}{l}\text { Space } \\
\text { organisation }\end{array}$ & atial & & & \\
\hline
\end{tabular}




\begin{tabular}{|c|c|c|c|}
\hline Hierarchy & $\mathrm{X}$ & $\begin{array}{l}\text { Seperation of } \\
\text { space } \\
\text { according to } \\
\text { natural land } \\
\text { contour } \\
\text {-determine the } \\
\text { acces for user }\end{array}$ & $\begin{array}{l}\text { Vertical } \\
\text { hiereachy- } \\
\text { limited space- } \\
\text { shortest the } \\
\text { distance }\end{array}$ \\
\hline Building layout & $x$ & $\begin{array}{l}\text { Integrated } \\
\text { space and } \\
\text { maximum } \\
\text { social } \\
\text { interaction } \\
\text {-buffer zone } \\
\text { avoiding } \\
\text { interrupted } \\
\text { activity }\end{array}$ & $\begin{array}{l}\text { Multipurpose } \\
\text { use of } \\
\text { staircase, } \\
\text { integrate } \\
\text { vertical space- } \\
\text { minimum } \\
\text { wastage of } \\
\text { space }\end{array}$ \\
\hline Zoning & $X$ & $\begin{array}{l}\text { Maximum use } \\
\text { of multipurpose } \\
\text { space and } \\
\text { open space } \\
\text { allow free flow } \\
\text { ventilation }\end{array}$ & $\begin{array}{l}\text { Radial } \\
\text { arrangement } \\
\text { with focal on } \\
\text { courtyard- } \\
\text { minimize the } \\
\text { walking } \\
\text { distance within } \\
\text { building-allow } \\
\text { maximum } \\
\text { usage }\end{array}$ \\
\hline
\end{tabular}

Finding on Seri Petaling mosque shows that the architectural elements adapted in the mosque design blends in with the surrounding context from the aspect of climatic consciousness. It also reflects on the building design style that portrays a sense of humbleness in its architectural form and space. Aside from that, An-Nahdhah mosque shows that the mosque considers the element of sustainable in its design construction. It can be seen on the planning of mosque building as overall. Even though both mosques had their limitation and been controlled by different policy making, but at least they can have a design that concern the community more within their capability.

Each element helps to improve the surrounding community. As example, design that uses natural planning allows natural ventilation into the building. The implementation of a buffer zone and strategic location also act as natural surveillance for crime prevention to the nearby neighbourhood (Aldrin A., 2012). Even though the setting of this mosque is different with different major society beliefs and culture, limitation of costing and also authority 
policies but it can portray the implementation of passive design approach. Even though sustainable approach is not the major intention of the mosque design but it is the responsibility of designer to fulfill the needs of the community.

Mosque located in a non-Muslim country may portray less sustainable approach due to the authority limitation but when they are designed according to the needs of the society the authority limitations may be overcome. In a democratic country, communal voice are much dominant and desire to live in a better quality environment is well put forth by the modern society regardless of age, gender or ethnicity. In brief, both Sri Petaling and An-Nahdah mosque expresses how sustainable design can improve the quality of space for the user and beneficial in increasing the communal quality of life. The above discussion also highlights how sustainable characteristics can be adopted in the future mosque design. It is vital because many current mosques devoid the importance of sustainable design characteristics that much emphasis on image making and aesthetical approach.

\subsection{Conclusion}

Comparative study helps to display the needs of communal design referring to sustainable characteristics of architectural form and space and can give big impact on the life of the community. The designer should design the mosque by understanding the needs of the society and referring to the guideline provided by scholars. It is not only vital for the society but representing the spiritual of the Islamic religion as mention in Quran and hadith. The daily life of the community especially Muslim believer will be different when their surrounding building reacts with environmental with give advantage of improving their life. It will bring the mankind close to ALLAH and make other believer comfort. That is the reason why it is important for a modern mosque to have sustainable characteristics. Applying the essence of sustainable feature, the transition of better communal mosque in the future will be the experience that also contributes to the development of sustainable community.

\section{Acknowledgement}

Acknowledgement to the Malaysian Ministry of Higher Education for the scholar and to the supervision grant by my supervisor.

\section{References}

Abd. Rahman, A. (2007). Gerakan Islam tradisional di Malaysia: Sejarah pemikiran jama'at tabligh dan Darul Arqam. Shah Alam: Karisma Publication.

Abu Samah, Z. et al. (2013). Translating quality care factors to quality space: design criteria for outpatient facility. Procedia - Social and Behavioral Sciences, 105, 265-272. 
Aldrin A. M., Najib, M. S., \& Siti, R. M. S. (2012). Fear of crime in Gated and Non-Gated Residential Areas. Procedia - Social and Behavioral Sciences, 35, 63-69.

Alice, S. I. (2008). The influence of Islamic political ideas on the design of state mosque in peninsular west Malaysia. PhD Dissertation. Queensland University of Technology, Brisbane Australia.

Conway, H., \& Roenisch, R. (1994). Understanding Architecture: An introduction to Architecture and Architecture History (2nd ed). London: Routledge, Taylor and Francis Group.

Fiske, J. (1990). Introduction to communication studies. London: Routledge.

Hafazah, A. K. (2012). Low cost housing environment: Compromising quality of life?. Procedia - Social and Behavioral Sciences, 35, 44-53.

Hamid, G. G. (2012). The position of mosque in Islamic cities and its location design in new cities. Damascus University, 28(1).

Hawkes, T. (2003). Structuralism and semiotic. London: Routledge.

Hillier, J., \& Hanson, B. (1996). Space is a machine: A configurational theory for architecture. Great Britain: Cambridge University Press.

Holod, R., \& Khan, H. U. (1997). The contemporary mosque architects, clients, and designs since the 1950s.

Keles, R. (2012). The quality of life and the environment. Procedia - Social and Behavioral Sciences, 35, 23-32.

Marans, R. W.(2012). Quality of urban life studies: An overview and implications for environment-behaviour research. Procedia - Social and Behavioral Sciences, 35, 9-22.

Meehan, P. J. (1987). Truth against the world:frank lloyd wright speaks about organic architecture. U.S.A: Wiley Interscience Publications.

Mohd Noor, M., Siti, F. M., \& Ismaniza, I. (2012). Islamic philosophy on behaviour - based environmental attitude. Procedia - Social and Behavioral Sciences, 49, 85-92.

Mulhall, A. (2002). In the filed: Notes on observation in qualitative research. Methodological issues in nursing research. Blackwell Publishing.

Nadzirah, Z., Siti, M. A., \& Zarita, A. (2011). Light and space: user's perception towards energy efficient buildings. Procedia - Social and Behavioral Sciences, 36, 51-60.

Peck, M. S. (1998). The different drum: Community making and place. A Touchstone Book: Simon \& Schuster.

Rosniza, O., Nila, I., \& Yahaya, A. (2007). A typological study of mosque internal spatial arrangement: A case study on Malaysian Mosque (1700-2007). Centre for conservation studies and Record: Faculty of Built Environment, University Malaya.

Shatha, M. (2004). Local Identity of modern Amman-Jordan: A perceptual approach towards identifying An Intersubjective and Shared Architectural Schemata. Urban Design International, 9(3),119-130. 
Spahic, O. (2010). Some lessons from Prophet Muhammad S.A.W in Architecture: The Prophets mosque in Madinah. Intellectuals discourse, 18(1),115-140.

Tajuddin, M. R. (1998). The mosque as a community development centre: Programme and architectural design guidelines for contemporary Muslim societies. Universiti Teknologi Malaysia.

Wates, N., \& Knevitt, C.(1987). Community architecture: how people are creating their own environment.(Kindle Edition). UK: Routledge.

Wright, F. L. (1939). An organic of architecture: The architecture of democracy. London: Land Humpries.

Zafrullah, M., \& Tajuddin, M. (2009). Islamic architecture Evolution: Perception and Behaviour. Procedia - Social and Behavioral Sciences, 49, 293-303. 